\title{
REKAYASA PROTOTIPE ALAT UJI CHLOR UNTUK INDUSTRI AIR MINUM ISI ULANG
}

\author{
Oleh : \\ Yuni Adiningsin ${ }^{*}$ \\ ABSTRACT
}

\begin{abstract}
The enginereed equipment was simply made by comparing colour yielded by sample with comparator colour. In the testing of free Chlor for refill drinking water the equipment reads accordingly to the standard of SNI. Its maximum reading is $0,1 \mathrm{mg} / \mathrm{l}$. For the value of more than $0,1 \mathrm{mg} / 1$, should be read by a titration method. This equipment production was $50 \%$ and $86,6 \%$ cheaper for the reagent than the commercial ones.
\end{abstract}

Key words : free chlor testing instrument, refill drinking water, enginereed equipment

\section{PENDAHULUAN}

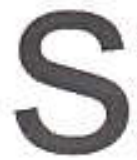

aat ini jumlah industriair minum isi ulang (AMIU) mengalami perkembangan yang sangat pesat. Hal tersebut menyebabkan terciptanya situasi pasar yang sangat kompetitif yang dapat berdampak luas, antara lain terhadap mutu AMIU yang ada di pasaran. Walaupun belum dikenakan peraturan yang mengharuskan produknya memenuhi syarat SNI, namun diharapkan pengusaha pengolah air minum ini memahami dan menerapkan cara produksi yang baik, sehingga masyarakat tidak dirugikan.

Beberapa industri air minum isi ulang menggunakan air PDAM sebagai bahan bakunya dimana air tersebut telah mengalami proses Chlorinasi sebagai desinfektan. Sehingga apabila ada sisa chlor yang melebihi ambang batas yang diijinkan yaitu maksimal 0,1 mg/l (SNI 01 3553-1996), dikhawatirkan dapat berpengaruh pada tubuh manusia karena bersifat racun.

Untuk mendapatkan mutu yang konsisten perlu dilakukan pemeriksaan kadar chlor yang dilakukan sacara periodik. Alat tersebut saat ini merupakan produk luar negeri sehingga untuk memperoleh alat tersebut cukup sulit terutama untuk Industri Kecil Menengah (IKM). Untuk itu perlu adanya rekayasa prototipe alat agar mudah diperoleh pengusaha IKM dengan harga yang terjangkau dan mudah penggunaannya.

\section{BAHAN DAN METODA}

Perekayasaan dilakukan selama 10 bulan (Maret-Desember 2005) di Balai Riset dan Standardisasi Industri dan Perdagangan Samarinda. Perekayasaan dilakukan dengan beberapa tahapan yaitu menentukan metode uji dengan menggunakan metode DPD (N,N-Diethyl-pPhenylenediamine) (Berman). Warna pembanding uji Chlor dibuat berdasarkan larutan standar yang telah ditetapkan konsentrasinya. Untuk validasi prototipe dilakukan uji coba dengan menggunakan sembilan sampel air minum isi ulang. Hasil uji tersebut dibandingkan dengan spektrofotometer (Hach DR 2000), yang telah terkalibrasi dengan panjang gelombang $530 \mathrm{~nm}$. Bahan dasar alat rekayasa terbuat dari kayu sebagai rangkanya dan peralatan gelas untuk alat pengujiannya.

\footnotetext{
Penelifi Baristand industri Santarinda
} 


\section{HASIL DAN PEMBAHASAN}

Dari hasil perekayasaan alat yang telah dilakukan menghasilkan suatu prototipe alat uji parameter Chlor bebas terutama untuk Air Minum Isi Ulang. Prinsip kerja alat ini adalah membandingkan warna sampel dengan warna pembanding yang ada di alat rekayasa. Batas maksimal warna pembanding di alat adalah $0,1 \mathrm{mg} / \mathrm{l}$ atau setara dengan nilai maksimal air minum yang aman dikonsumsi.

Penetapan warna pembanding berdasarkan pembentukkan warna yang dihasilkan dari konsentrasi larutan standar yang telah dibuat kemudian diuji dengan spektrofotometer. Tingkat warna dari beberapa konsentrasi tersebut diabadikan dalam lembar warna pembanding. Di mana tingkat warna yang dicantumkan di alat yaitu $0,05 \mathrm{mg} / \mathrm{l}$ dan $0,1 \mathrm{mg} / \mathrm{l}$ (standar maksimal air minum).

Hasil perekayasaan berupa kotak yang berisi peralatan gelas seperti buret, pipet volumetrik, Erlenmeyer, beaker glass, botol sampel, botol reagent, peralatan titrasi serta warna pembanding (gambar 1).

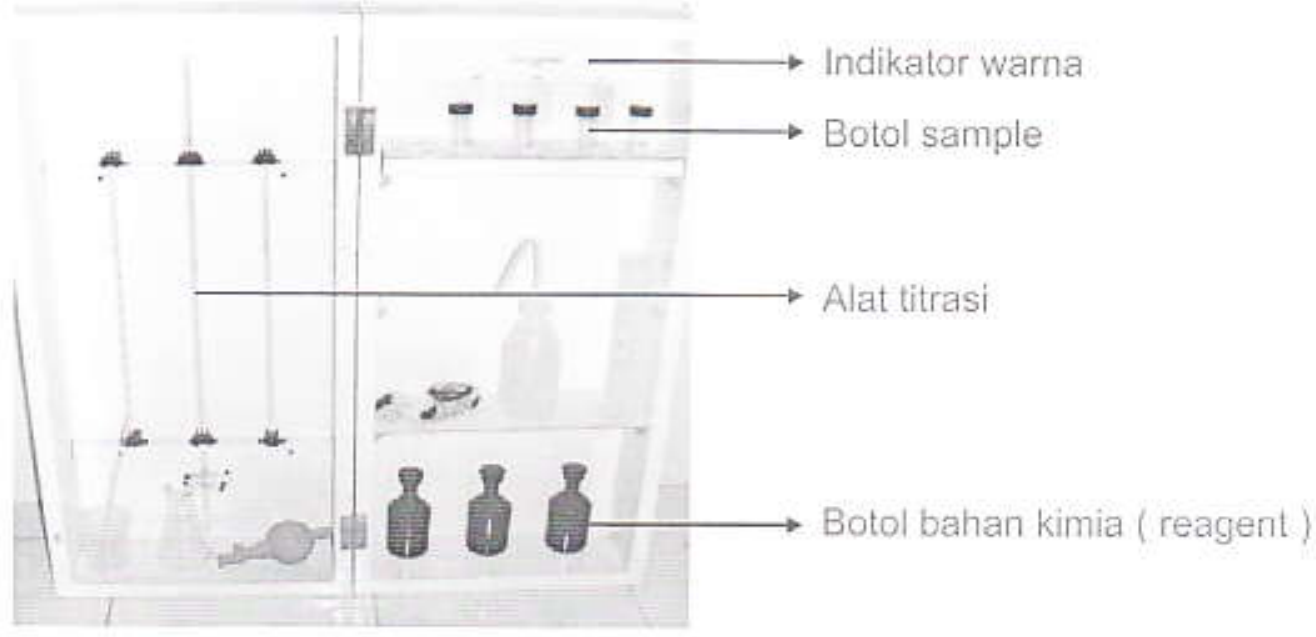

Gambar 1. Hasil rekayasa alat uji Chlor bebas

Prinsip kerja alat yaitu dengan cara mereaksikan $50 \mathrm{ml}$ sampel dengan $2,5 \mathrm{ml}$ DPD reagent yang telah dikondisikan pHnya dengan $2,5 \mathrm{mi}$ phosphate buffer. Setelah warna merah muda timbul (pengadukan selama 1 menit), kemudian dibandingkan dengan warna pembanding yang ada di alat. Untuk pembacaan lebih dari $0,1 \mathrm{mg} / \mathrm{l}$, prinsip kerja alat sama seperti di atas kemudian dititrasi dengan larutan FAS hingga warna merah muda hilang. Pembacaan jumlah kadar Chlor bebas menggunakan persamaan:

$$
\text { Mg free active chlorine } L=\frac{a \times 0,1 \times 1000}{b}
$$

\section{Keterangan :}

$a=m L F A S \quad b=m L$ sample

\section{Asumsi :}

$1 \mathrm{~mL} F A S H^{\prime \prime} 0,1 \mathrm{mg}$ free active chlorine 


\section{Validasi alat rekayasa}

Validasi dilakukan dengan cara membandingkan hasil uji alat rekayasa dengan spektrofotometer yang telah terkalibrasi. Pengujian dilakukan untuk sampel Air Minum Isi Ulang (Tabel 1).

Tabel 1. Perbandingan hasil uji alat rekayasa terhadap spektrofotometer

\begin{tabular}{|c|c|c|}
\hline Sampel AMIU & Alat Rekayasa $(\mathrm{mg} / \mathrm{l})$ & Spektrofotometer $(\mathrm{mg} / \mathrm{l})$ \\
\hline 1 & 0 & 0 \\
\hline 2 & Kurang dari 0,05 & 0,01 \\
\hline 3 & Kurang dari 0,05 & 0,01 \\
\hline 4 & Kurang dari 0,05 & 0,01 \\
\hline 5 & Kurang dari 0,05 & 0,01 \\
\hline 6 & Kurang dari 0,05 & 0,02 \\
\hline 7 & Kurang dari 0,05 & 0,01 \\
\hline 8 & Kurang dari 0,05 & 0,01 \\
\hline 9 & 0 & 0 \\
\hline
\end{tabular}

Pembacaan alat adalah berdasarkan kemunculan warna merah muda yang terbentuk dimana intensitas warna tersebut sesuai dengan jumlah Chlor bebas yang bereaksi dengan gugus Amine dari DPD reagent. Semakin tinggi kadar Chlor bebas semakin tinggi pula intensitas warna merah muda yang muncul. Alat mempunyai nilai yang setara dengan 0,05 $\mathrm{mg} / \mathrm{l}$ apabila warna menunjukkan merah muda dan nilai setara $0.1 \mathrm{mg} / \mathrm{l}$ apabila warna menunjukkan lebih tua dari merah muda.

Hasil uji pembacaan a lat rekayasa menunjukkan nilai di bawah $0,05 \mathrm{mg} / \mathrm{l}$ sesuai dengan lembar warna pembanding. Untuk pembacaan spektrofotometer menunjukkan nilai kadar Chlor bebas yang sesungguhnya yaitu hasil uji menunjukkan nilai di bawah $0.05 \mathrm{mg} / \mathrm{l}$. Jadi nilai hasil uji alat rekayasa sama dengan hasil uji spektrofotometer. Kelemahan dari alat rekayasa dibanding dengan spektrofotometer adalah tingkat ketelitian pembacaannya, dimana alat mempunyai ketelitian pembacaan hanya $0,05 \mathrm{mg} / \mathrm{l}$.

\section{Aspek Teknologi}

Prinsip kerja alat rekayasa sama dengan alat test kit yang ada di pasaran yaitu membandingkan hasil dengan warna pembanding. Dasar pembuatan warna pembanding alat adalah ambang batas Chlor bebas yang dijinkan untuk air minum (SNI 01-3553-1996) yaitu 0,1 $\mathrm{mg} / \mathrm{l}$. Kelebihan dengan alat yang ada di pasaran, alat rekayasa dapat digunakan untuk pengujian secara kuantitatif bila hasil uji menunjukkan warna di atas $0,1 \mathrm{mg} / \mathrm{l}$, sehingga alat rekayasa ini dapat digunakan untuk keperluan lain seperti uji Chlor di kolam renang dan lain-lain. Alat ini telah dilakukan uji coba di industri Air Minum Isi Ulang dan tidak terdapat kendala pada saat industri tersebut melakukan pengujian serta dirasakan penggunaan alat ini mudah dan cepat. 


\section{Aspek Ekonomis}

Total harga alat rekayasa yang telah dibuat dibandingkan dengan harga alat pabrikan sebagai terlihat pada tabel 2. Dari analisa ekonomi di atas terlihat bahwa harga alat uji rekayasa chlor lebih murah $50 \%$ dari harga alat pabrikan yang sudah ada. Sedang untuk penggunaan bahan kimia, pengujian Chlor bebas menggunakan alat rekayasa lebih murah $86,6 \%$ dibanding penggunaan bahan kimia untuk alat pabrikan.

\begin{tabular}{|l|lc|lc|}
\hline \multicolumn{1}{|c|}{ Parameter } & \multicolumn{2}{|c|}{ Alat Rekayasa } & \multicolumn{2}{c|}{ Alat Pabrikan } \\
\hline Harga alat & Rp. $518.000,-$ & Rp. $1.037 .400,-$ \\
\hline Biaya penggunaan bahan kimia & Rp. & $1.000,-$ & Rp. & $7.448,-$ \\
\hline
\end{tabular}

\section{KESIMPULAN DAN SARAN}

Hasil rekayasa alat menunjukkan bahwa alat ini dapat digunakan pada tingkat ketelitian pembacaan setara dengan $0,05 \mathrm{mg} / \mathrm{l}$ dengan harga alat rekayasa $50 \%$ dan penggunaan bahan kimia ( reagent) $86,6 \%$ lebih murah dari harga pabrikan yang ada di pasaran.

Perlu penelitian lanjutan untuk pembuatan alat rekayasa uji Chlor yang mempunyai tingkat ketelitian pembacaan yang lebih rendah.

\section{DAFTAR PUSTAKA}

American Public Health Association, 1998. Standard Methods For The Examination Of Water and Waste Water, America

Anonim, 1996. Standar Nasional Indonesia (SNI 01-3553-1996), Badan Standar Nasional, Jakarta.

Berman A.M, 2000. DPD Colorimetric Testing For Chlorine, Dep Of Natural Resourch

Hanafiah Ali Kemas, 1995. Rancangan Percobaan, PT Raja Grafindo Persada, Jakarta

Othmer Kirk, 1992. Encyclopedia Of Chemical Technology, Vol.5, New York

Steel Robert, 1995. Prinsip dan Prosedur Statistika, Gramedia Pustaka Utama, Jakarta

Suprapto Hardi, 1988. Teknologi Air I, Institut Pertanian Bogor, Bogor 